Dicle Tıp Dergisi / Dicle Medical Journal (2017) 44 (1) : 43 - 50

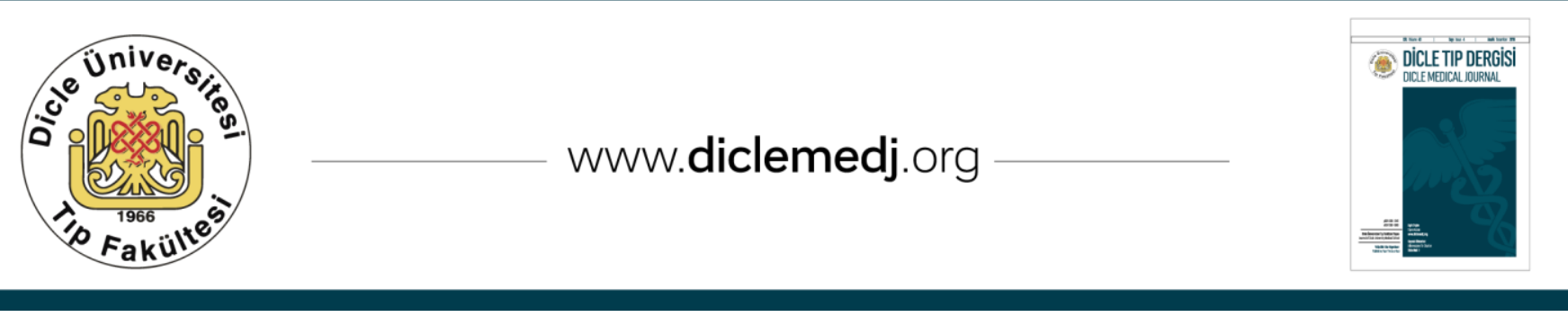

Özgün Araştırma / Original Article

\title{
Meme kanserinde Kv 1.3 ve Kv 10.1 voltaj bağımlı potasyum kanallarının inhibisyonunun oksidatif stres üzerindeki rolü
}

\author{
Didem Turgut Coşan¹, Çağrı Öner¹, Ahu Soyocak ${ }^{1}$ Evrim Metcalfe², Mustafa Djamgoz³ \\ 1 Eskişehir Osmangazi Üniversitesi, Tıp Fakültesi, Tıbbi Biyoloji Anabilim Dalı, Eskişehir, Türkiye \\ 2 Eskişehir Osmangazi Üniversitesi, Tıp Fakültesi, Radyasyon Onkolojisi Anabilim Dalı, Eskişehir, Türkiye \\ 3 Neuroscience Solutions To Cancer Research Group, Department Of Life Sciences, Imperial College London Sw7 2az, UK
}

Geliş: 24.08.2016; Revizyon: 20.12.2016; Kabul Tarihi: 21.12.2016

Özet

Amaç: Reaktif oksijen türevleri oksidatif stres, iyonize radyasyon maruziyeti, iskemi-reperfüzyon hasarı ve kanseri içeren fizyolojik ve patolojik durumlarda artmaktadır. Çalışmamızda meme kanser hücrelerinin farklılaşmasında ve çoğalmasında etkili olduğu düşünülen voltaj kapılı potasyum kanallarının inhibisyonunun etkilerini gözlemek amaçlandı.

Yöntemler: Farklı karakterlerdeki meme kanseri hücrelerine bu potasyum kanallarına özgü siRNA'ların transfeksiyon işlemi yapıldı. İnkübasyon sonrasında hücre lizatları hazırlanarak antioksidan ve oksidan seviyeleri belirlendi. Elde edilen verilerle oksidatif stres hesaplandı. Sürekli değişkenlerin normal dağılıma uygunluğu Kolmogorov-Smirnov testi kullanılarak yapıldı. Normal dağılım gösteren değişkenlerin gruplar arasındaki karşılaştırmaları tek yönlü varyans analizi ile değerlendirildi. Çoklu karşılaştırmalar ise Tukey HSD testi ile gerçekleştirildi.

Bulgular: Kanal inhibisyonu ile invaziv olmayan karakterdeki MCF-7 hücrelerinin oksidatif stres seviyesinde düşüş olduğu gözlendi. İnvaziv karakterdeki MDA-MB-231 hücrelerinde ise Kv 1.3 siRNA transfekte edilen grupta oksidatif stres seviyesinde düşüş belirlenirken, Kv 10.1 siRNA transfekte edilen grupta artış belirlendi.

Sonuç: Voltaj kapılı potasyum iyon kanallarının inhibisyonunun kanser hücrelerinde oksidatif stres oluşturabileceği belirlenmiştir. Ayrıca, çalışmamızdaki en önemli bulgu kanser hücrelerinde voltaj bağımlı potasyum kanallarının oksidatif stres üzerinde etki yapabileceği ve bunun hücrelerin metastatik karakteri ve iyon kanalı türü ile bağlantılı olmasidır.

Anahtar kelimeler: Kv 1.3; Kv 10.1; meme kanseri; oksidatif stres

DOI: $10.5798 /$ dicletip.298591

Yazışma Adresi / Correspondence: Didem Turgut Coşan, Eskişehir Osmangazi Üniversitesi, Tıp Fakültesi, Tıbbi Biyoloji Anabilim Dalı, Eskişehir,

Türkiye, Email: dcosan@gmail.com 


\title{
Inhibition of Kv 1.3 and Kv 10.1 voltage gated potassium channels role on oxidative stress in breast cancer
}

\begin{abstract}
Objective: Reactive oxygen species especially increase in physicological and pathological conditions including oxidative stress, ionised radiation, ischemia-reperfusion damage and cancer. We aimed to observe the effects of voltage gated potassium channels which take part in differentiation and proliferation of breast cancer cells by their inhibition.

Methods: Potassium channel siRNAs were transfected to different characteristic breast cancer cells. Cell lysates were prepared after incubation and then total antioxidant and oxidant levels were determined. The level of oxidative stress was calculated by obtained data. Normal distribution of the continuous variables was enabled using the KolmogorovSmirnov suitability test. Comparisons between groups of normally distributed variables were evaluated using OneWay variance analysis. Tukey HSD test was used for multiple comparisons.

Results: It was observed that inhibition of potassium channels caused to reduce oxidative stress level in non-invasive MCF-7 breast cancer cells. Furthermore, in invasive MDA-MB-231 breast cancer cells, it was determined that inhibition of Kv 1.3 caused to reduce oxidative stress level while inhibition of Kv 10.1 caused to induce oxidative stress level.

Conclusion: It was determined that inhibition of voltage gated potassium channels might be affected oxidative stress in cancer cells. Also, the most important result of our study is the possible effect of voltage gated potassium channels on oxidative stress and this effect depends on metastatic character and sort of ion channel in cancer cells.
\end{abstract}

Keywords: Breast cancer, Kv 1.3, Kv 10.1, Oxidative Stress

\section{GíRiş}

Metabolik işlemler sonucunda serbest radikal adı verilen bileşikler oluşmaktadır. Sağlıklı hücrelerde serbest radikallerin organizmaya zarar vermesi savunma sistem tarafindan engellenmektedir. Serbest radikaller, transkripsiyon faktörlerini aktif hale getiren ve hücreler arası haberleşmede görev alan ikinci habercilerden biridir [1]. Metabolizma genelde serbest radikallerin oluşum hızı ile oluşan serbest radikallerin etkisizleștirme hızının dengede tutulmasını sağlamaktadır. Eğer bu denge bozulursa, serbest radikallerin zararlı etkileri (reaktif oksijen türevleri; ROS) hücrelerden başlayarak sistemlere kadar zarar vermektedir. ROS'ların metabolizmada karbonhidrat, protein ve lipitlerin oksidasyonuyla olușturacağ engellenmesini sağlayan savunma mekanizması antioksidanlardır. Antioksidanların serbest radikallere karşı koruyucu rol oynadığını çeşitli çalışmalarda in vivo ve in vitro deneyler yapılarak gösterilmiştir [2]. Radikallerin aşırı reaktif yapılarına bağlı olarak, hücresel bileşenlerdeki sonuçlanacak zararın önlenmesi antioksidanların görevidir. Artan ROS seviyeleri oksidatif stresi ile birlikte, iyonize radyasyon maruziyeti, iskemi-reperfüzyon hasarı ve çoğu kanseri de içeren fizyolojik ve patolojik durumlarda görülmektedir. Serbest radikaller ve oluşturdukları ROS'lar apoptozun habercisi ve tetikleyicisi olarak görev yapmaktadırlar [1].

Yapılan çalışmalarda, kanser oluşumunda görülen hücre zarındaki lipit peroksidasyonu ve tümör hücrelerinin büyümelerinin kontrol edilmesi gibi birçok farklı basamağın ROS'larla ilişkili olduğunu bildirilmiştir $[3,4]$. Başta gastrointestinal sistemde görülen kanserler olmak üzere, çoğu kanserin gelişiminde serbest radikaller tarafından oluşan ROS'ların etkisinin olduğu bildirilmiştir [5].

Voltaj kapılı iyon kanalları geniş bir gen ailesinin üyeleridir. $\mathrm{Bu}$ ailedeki birçok iyon kanalı hücre zarının depolarizasyonu sonucunda açllp yüksek derecede voltaja 
bağımlılık gösterir. Voltaj kapılı potasyum kanalları (VGPC) birbirine eş olmayan alt birimlerden oluşan bir heteromultimerdir. Heteromultimer kanallar, kanala farklı görevler sağlamaktadır. Toksin bağlanma bölgesi ve tek bir iyon geçişini sağlayan kanal, farklı yapı ve özellik gösteren 2 ile 13 arasında farklı kanal oluşmasını sağlamaktadır. VGPC genellikle hücrelerin zarında eksprese olup depolarizasyonla aktif hale gelirler. Dinlenme sırasında zar potansiyelinin düzenlenmesini ve aksiyon potansiyelinin sıklığını kontrol ederler [6]. VGPC tümör hücreleri başta olmak üzere pek çok hücre tipinin çoğalmasında role sahiptir. Ayrıca, VGPC'ler farklılaşma, apoptoz, adezyon, göç ve hacim kontrolü gibi birçok fizyolojik fonksiyona sahiptir. Bu fonksiyonlar primer ve metastatik tümör oluşumu ile de ilişkili olabilmesi nedeniyle, VGPC'lerin fonksiyonlarındaki herhangi bir değişim ya da artışın sağlıklı hücrelerde onkogenik etki yapabileceğini desteklemektedir [7]. VGPC'ler çoğu kanser hücresinin proliferasyonunda, hücre içi haberleşmede görevli birçok sinyal molekülünün transkripsiyonu ile translasyonunda ve hücre döngüsünün evreleri arasındaki kontrollerin düzenlenmesinde görev almaktadır [7]. $\mathrm{Bu}$ nedenle, kanser hücrelerinde de potasyum kanallarının tedavi ve yeni biyomarkerların tanımlanması tedavi için önemli bir yere sahiptir.

Çalışmamızda gen bölgesi susturulan iki potasyum kanalından biri KCNA grubundan Kv 1.3 potasyum kanalı, diğeri KCNG grubundan Kv 10.1 potasyum kanalıdır [8]. Kv $1.3 \mathrm{~T}$ lenfositlerinde voltaj bağımlı $\mathrm{Ca}$ kanallarıyla beraber çalışan bir voltaj bağımlı potasyum kanalıdır. Kv 1.3 immün hücrelerindeki etkinliği ve hücre proliferasyonunda görev aldığı bilinmektedir [9]. Kv 1.3, Kv 1.5, Kv 10.1 ve $\mathrm{Kv} 11.1^{\prime}$ 'in apoptozun düzenlenmesinde etkili oldukları bildirilmiştir [10]. DNA metilasyonu gibi epigenetik değişimler pankreas kanserinde Kv 1.3 kanalı tarafından düzenlendiği belirtilmiştir [11]. Sağlıklı meme epiteline göre Kv 1.3'ün ekspresyonu meme kanserinde arttığl; ayrıca geç evre meme tümörlerinde de $\mathrm{Kv}$ 1.3'ün ekspresyonunun arttığı belirlenmiştir [12]. Kv10.1 genellikle beyinde eksprese olan bir kanal olup sinir sistemi dışında sağlıklı dokulardaki etkisi tam olarak bilinmemektedir. Ancak Kv 10.1 potasyum kanalı az miktarda da olsa plasentada, testiste ve böbrek üstü bezlerinde de bulunmaktadır [10]. Yapılan çalışmalar Kv10.1'in, tanı ve tedavi potansiyeline sahip olduğu ve kanserle ilişkili çok önemli bir tümör belirleyicisi olduğunu desteklemektedir $[13,14]$. Pardo ve arkadaşlarının yaptığ çalışmada primer tümörde Kv 10.1 ekspresyonunun arttığl, Kv1.3 potasyum kanalının aşırı eksprese olduğu bildirilmektedir [13].

Çalışmamızda meme kanser hücrelerinin farklılaşmasında ve çoğalmasında etkili olduğu düşünülen Kv 1.3 ve Kv 10.1 voltaj kapılı potasyum kanallarının inhibisyonunun, oksidatif stres başta olmak üzere antioksidan ve oksidan seviyeleri üzerindeki etkilerini ortaya koymak amaçlanmıştır.

\section{YÖNTEMLER}

Hücrelerin yetiştirilmesi ve transfeksiyon: Meme kanser hücre dizileri (MCF-7 ve MDA-MB-231) (ATCC, Washington D.C., USA) \%10 Fetal Bovin Serum (FBS; Gibco, UK) ve $\% 1$ Penisilin/streptomisin içeren fenol red'li Dulbecco's Modified Eagle's Medium (DMEM; Gibco, UK) besiyeri kullanılarak $37^{\circ} \mathrm{C}$ 'de $\% 5$ CO2'li ortamda çoğaltılıp yeterli sayıya ulaştırıldı.

MCF-7 ve MDA-MB-231 hücrelerine Kv 1.3 ve Kv 10.1 voltaj kapılı potasyum kanallarına özgü siRNA'lar transfekte edildi. Kv 1.3 ve $\mathrm{Kv} 10.1$ siRNA'ları ile serumsuz besiyeri; transfeksiyon ajanı (Thermo Scientific, USA) ile serumsuz besiyeri ayrı ayrı 10 dakika inkübe edildi. İnkübasyon sonunda hazırlana karışımlar birleştirilip üzerine $\% 10$ FBS ve $\% 1$ Penisilin/streptomisin içeren fenol red'li DMEM ilave edilerek 24 saat boyunca inkübe edildi. 
A

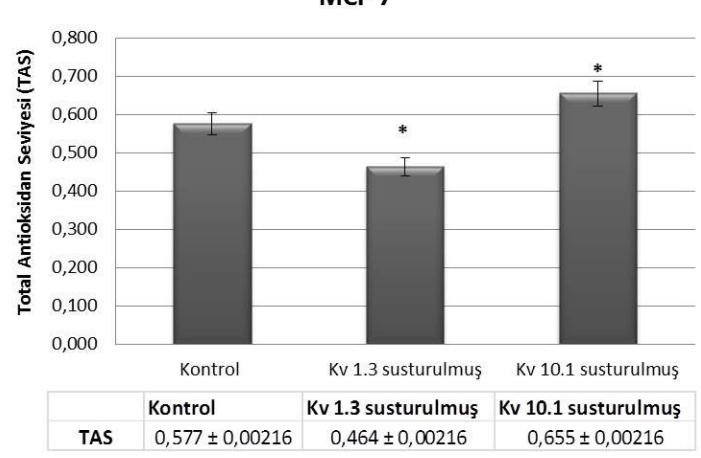

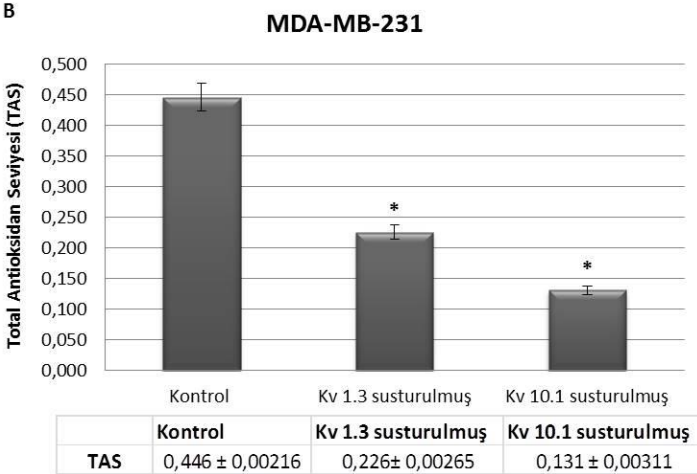

Şekil 1. MCF-7 ve MDA-MB-231 meme kanser hücrelerinde Total Antioksidan Seviyeleri (TAS). A. Kv 1.3 ve Kv 10.1 voltaj kapılı potasyum kanalı inhibe edilmesi MCF-7 meme kanseri hücrelerinde belirlenen total antioksidan seviyesi. B. Kv 1.3 ve Kv 10.1 voltaj kapılı potasyum kanalı inhibe edilmesi MDA-MB-231 meme kanseri hücrelerinde belirlenen total antioksidan seviyesi. $(* \mathrm{P}<0.001)$
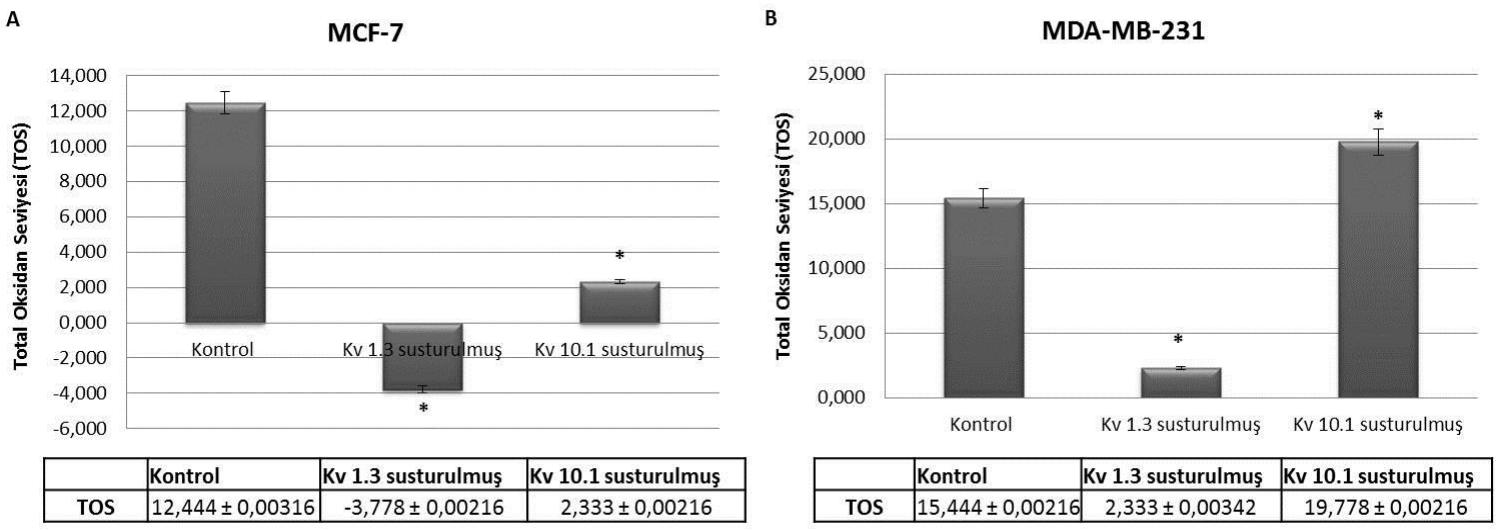

Şekil 2. MCF-7 ve MDA-MB-231 meme kanser hücrelerinde Total Oksidan Seviyeleri (TOS). A. Kv 1.3 ve Kv 10.1 voltaj kapılı potasyum kanalı inhibe edilmesi MCF-7 meme kanseri hücrelerinde belirlenen total oksidan seviyesi. B. Kv 1.3 ve Kv 10.1 voltaj kapılı potasyum kanalı inhibe edilmesi MDA-MB-231 meme kanseri hücrelerinde belirlenen total oksidan seviyesi. $(* \mathrm{P}<0.001)$
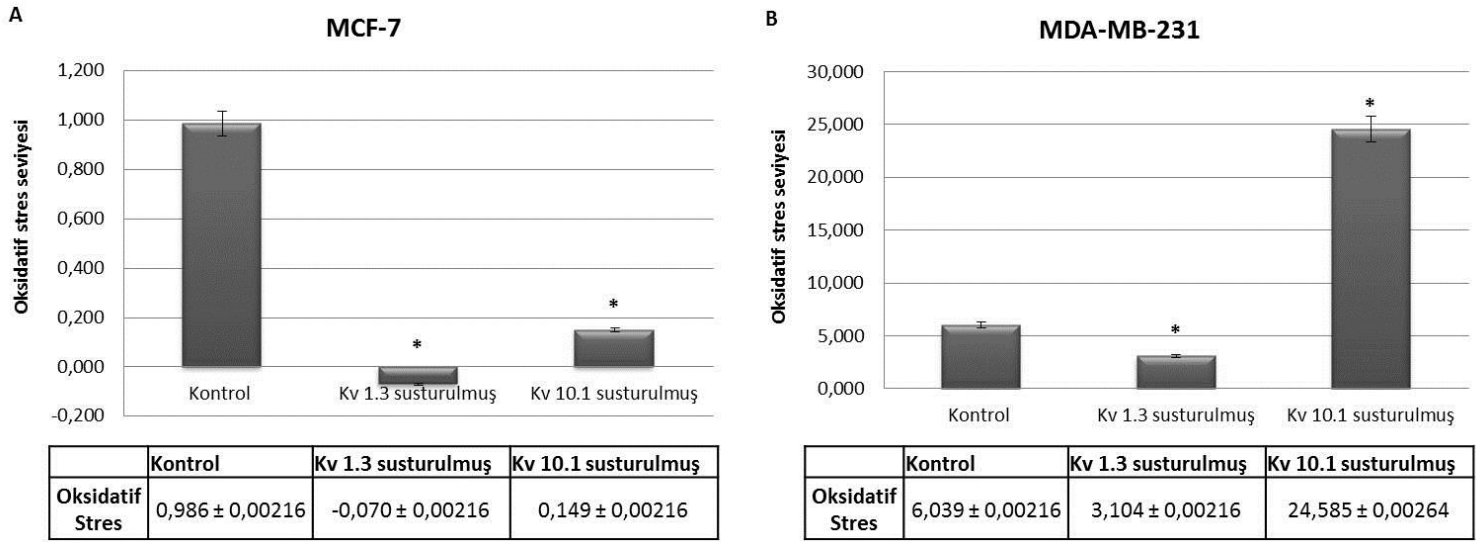

Şekil 3. MCF-7 ve MDA-MB-231 meme kanser hücrelerinde Oksidatif Stres Seviyeleri. A. Kv 1.3 ve Kv 10.1 voltaj kapılı potasyum kanalı inhibe edilmesi MCF-7 meme kanseri hücrelerinde belirlenen oksidatif stres seviyesi. B. Kv 1.3 ve Kv 10.1 voltaj kapılı potasyum kanalı inhibe edilmesi MDA-MB-231 meme kanseri hücrelerinde belirlenen oksidatif stres seviyesi. $\left({ }^{*} \mathrm{P}<0.001\right)$ 
Total antioksidan ve oksidan seviyelerinin belirlenmesi: İnkübasyon sonrasında hücre lizatları $50 \mathrm{mM}$ fosfat tamponu kullanılarak elde edildi. Total antioksidan ve oksidan seviyeleri (TAS; TOS) ticari kit kullanılarak belirlendi (RelAssay Diagnostics, Türkiye). Spektrofotometrede (Lab Systems, Finlandiya) hücre lizatlarının absorbansları 520 nm'de ölçülmüştür. Elde edilen antioksidan ve oksidan verileri formüldeki uygun yerlere konularak hücrelerde oluşan oksidatif stres belirlendi.

Oksidatif Stres: Total antioksidan seviyesi/total oksidan seviyesi x 100

İstatistiksel değerlendirme: Sürekli değişkenlerin normal dağılıma uygunluğu Kolmogorov-Smirnov testi kullanılarak yapıldı. Normal dağılım gösteren değişkenlerin gruplar arasındaki karşılaştırmaları tek yönlü varyans analizi (OneWay ANOVA) ile değerlendirildi. Çoklu karşılaştırmalar ise Tukey HSD testi ile gerçekleştirildi. Tablo ve grafiklerde ortalama \pm standart sapma kullanıldı. Tüm analizler IBM SPSS Statistics 21.0 paket programı kullanılarak yapıldı.

\section{BULGULAR}

MCF-7 hücrelerinde kontrol grubuna göre KV 1.3 voltaj kap1lı potasyum kanalı inhibe edilen hücrelerde total antioksidan seviyesi istatistiksel olarak önemli bir azalma gösterirken; Kv 10.1 voltaj kap1lı potasyum kanalı inhibe edilen hücrelerde ise istatistiksel olarak önemli derecede bir artma belirlendi (Şekil 1A.; P $<0.001$ ). MDAMB-231 hücrelerinde ise kontrol grubuna göre hem $\mathrm{Kv} 1.3$ hem de Kv 10.1 voltaj kapilı potasyum kanalı inhibe edilen hücrelerde total antioksidan seviyesinde istatistiksel olarak önemli derecede azalma gözlendi (Şekil 1B.; P < 0.001).

Her iki tip meme kanser hücrelerinde Kv 1.3 ve Kv 10.1 voltaj kapılı potasyum kanalı inhibisyonu sonucunda görülen total oksidan seviyeleri göz önünde bulundurulduğunda, MCF-7 hücrelerinde Kv 1.3 ve Kv 10.1 voltaj kapılı potasyum kanalları inhibe edilen hücrelerde kontrol grubuna göre istatistiksel olarak önemli derecede azalma gözlendi (Şekil 2A.; P < 0.001). MDA-MB-231 hücrelerinde kontrol grubuna göre $\mathrm{Kv} 1.3$ voltaj kapılı potasyum kanalı inhibe edilen hücrelerin total oksidan seviyesinde istatistiksel olarak önemli derecede azalma belirlenirken; Kv 10.1 voltaj kapilı potasyum kanalı inhibe edilen hücrelerde istatistiksel olarak önemli derecede artış gözlendi (Şekil 2B.; P < 0.001).

Total antioksidan seviyesi / total oksidan seviyesi x 100 formülü uygulanarak elde edilen oksidatif stres seviyeleri hesaplandi. Kontrol grubuna göre Kv 1.3 ile Kv 10.1 voltaj kapılı potasyum kanalı inhibe edilen MCF-7 hücrelerinde istatistiksel olarak önemli derecede azalma gözlendi (Şekil 3A.; $\mathrm{P}<$ 0.001). MDA-MB-231 hücrelerinde, oksidatif stres Kv 10.1 voltaj kapılı potasyum kanalı inhibe edilen hücrelerde kontrol grubuna göre istatistiksel olarak önemli derecede artış belirlenirken; Kv 1.3 voltaj kapılı potasyum kanalı inhibe edilen hücrelerde oksidatif stres kontrol grubuna göre istatistiksel olarak önemli derecede azaldığı hesaplandı (Şekil 3B.; P < 0.001).

\section{TARTIŞMA}

Potasyum kanalları homeostazın dengede tutulması için; görevi biten ya da ihtiyaç duyulamayan hücreler ile kanser hücrelerinin yok edilmesi gibi fizyolojik olaylarda kritik rol oynamaktadır. Hücre içi potasyum miktarında azalma, hücre ölümünün erken evresinde görülen zar potansiyelinin değişimini tetiklemektedir [15]. Hücre hacmi ve hücre içi potasyum miktarındaki değişimler, hücre zarında yer alan potasyum kanallarının çalışmasıyla beraber; hücre içine aşırı potasyum akışı ile de gözlenmektedir [16]. Potasyum kanallarının düzensiz çalışması sonucu kanser hücrelerinin proliferasyonunu etkilediği gözlemlenmiştir [17]. Potasyum kanallarının çeşitlerine ve bulundukları kanser hücresinin de özelliklerine göre voltaj bağımlı potasyum kanalları farklı özellik gösterebilirler. Yapılan bir çalışmada, hücre içine potasyum akışının LNCaP prostat kanser hücrelerine göre $\mathrm{PC}-3$ prostat kanser hücrelerinde daha fazla olduğu, potasyumakım yoğunluğunun prostat kanser hücrelerinin metastatik kapasitesi ile ilişkili olabileceği bildirilmiştir [18]. Ayrıca, bazı potasyum kanallarının meme kanseri gelişimde onkogenik; 
bazılarının ise tümör baskılayıcı potansiyele sahip olduğu gözlendi [7].

Meme kanseri kadınlarda en çok görülen kanser türü olup çevresel koşullar, genetik, serbest radikaller ve iyonize radyasyona maruz kalmak gibi hem endojen hem de endojen kaynaklardan oluşabilmektedir. Meme kanser hücrelerinin proliferasyonunun VGPC kanallarının inhibe edilmesiyle azaltılabileceği daha önce yapılan bir çalışmada bildirilmiştir [7]. Yapılan çeşitli çalışmalarla, meme kanserinde VGPC'lerin proliferasyon, hücre döngüsü, apoptoz ve metastazda etkili olduğu desteklenmiştir [7,19]. Oksidatif stresin çoğu kanserde olduğu gibi meme kanserinde de rol oynadığı bilinmektedir [20,21].

Kv 1.3 potasyum kanalı meme kanseri başta olmak üzere kolon ve prostat kanserinde aşırı eksprese olmaktadır [22]. İleri evre meme kanserli hastalara ait dokularda $\mathrm{Kv} \quad 1.3$ kanallarının ekspresyonu normal meme epiteline göre istatistiksel olarak önemli derecede $\operatorname{artt1ğ1}$ belirlenmiştir [12]. 60 meme kanserli örnekte yapılan bir çalışmada, $\mathrm{Kv} 1.3$ 'ün protein ekspresyonu immunohistokimyasal olarak araştırılmış ve normal meme epitelinde görülmemesine rağmen, meme kanser dokularının hepsinde $(\% 100)$ pozitif boyanmış olduğu gözlenmiş. Boyalı örneklerin \%60'ında yüksek, \%30'unda çok yüksek ve \%22'sinde düşük bulunmuştur [22]. Bir başka potasyum kanalı olan Kv 10.2'nin (KCNH5) küçük hücre dişı akciğer kanserinde (NSCLC); Kv 11.1'in (KCNH2) yumurtalık (over) kanserinde ve Kv1.3'ün (KCNA3) pankreatik kanseri ile meme kanserinde ekspresyonlarının değiştiği belirlenmiştir [8]. Kv 1.3 potasyum kanalları hücre zarında olduğu gibi mitokondrinin iç zarında da bulunabilmekte olup Margatoksin gibi mitokondriyi hedefleyen herhangi bir inhibitör ile indüklenmediği sürece de aktif halde bulunmaktadır [23]. Kv 1.3 ve benzeri büyük potasyum kanalları, direkt hedefleri olan ve mitokondride bulunan pro-apoptotik özellikteki Bax ve Bad proteinleriyle beraber hücre ölümünde rol oynayabilmektedir [24]. Mitokondrial iç zarda bulunan $\mathrm{Kv} 1.3$ potasyum kanalının inhibisyonu sonucunda da ROS miktarlarının arttığı çeşitli çalışmalarla desteklenmiştir [25-28]. Kv 1.3 potasyum kanalı kadar periferal kan lenfositlerinde, makrofajlarda, kanser olmayan ve kanser hücre hatlarının mitokondrisinde bulunan Kv 1.3 kanalının eksprese olduğu bildirilmiştir [29]. Çalışmamızda uyguladığımız Kv 1.3 kanalına özgü olan siRNA, MCF-7 ve MDA-MB231 meme kanser hücrelerinde mitokondrinin iç zarında bulunan Kv 1.3 potasyum kanalına kadar etkili olamaması nedeniyle oksidatif stresin azaltmış olabileceğini düşünmekteyiz.

İnsan embriyonik böbrek epitel hücresi olan HEK293 hücrelerinde katalaz kullanılarak oksidatif stres oluşturulması sonucu $\mathrm{KV} 11.1$ (hERG) kanalından potasyum akışını azaldığı belirlenmiştir [30]. Kv 10.1'in (KCNH1) mutant olması ya da eksikliği sonucu hücrede bulunan kanalın potasyum geçirgenliğini azalttığı; ancak bu azalmanın hücrenin kanserleşmesini engellemediği yapılan bir çalışmada bildirilmiştir [10]. Glioma, meme ve kolon kanserinde Kv 10.1 potasyum kanalının aşırı eksprese olduğu yapılan çalışmalarla bildirilmiştir [13, 31]. Yapılan çalışmalarla, Kv 10.1'in daha köyü huylu kanser türlerinde hücre göçünü düzenlediği bildirilmiştir. İlk olarak göç yeteneğine sahip ve yüksek miktarda Kv 10.1 eksprese edilen hücrelerinde, Kv $10.1^{\prime}$ in inhibe edilmesi bu hücrelerin proliferasyonunu ve göç yeteneğini azalttığ bildirilmiştir [32]. Meme kanserinde invaziv olmayan MCF-7 ve invaziv MDA-MB-231 meme kanser hücrelerinin her ikisinde de Kv 10.1 ekspresyonu belirlenmiş olup [33,34], invaziv meme karsinomlarında bu ekspresyonlarının daha da arttığı [35] yapılan çalışmalarla desteklenmiştir. Kv 10.1 invaziv meme kanser hücre hattında daha aktif olması sonucunda $\mathrm{Kv} 10.1$ kanalının inhibisyonu MDA-MB-231 invaziv meme kanseri hücrelerinde oksidatif stresi arttırmaya yaramıştır.

Sağlıklı hücrelerde antioksidan ve oksidan dengesi bozulmadiğı durumlarda oksidatif stres görülmemektedir. Dışarıdan sağlıklı hücrelere herhangi bir uygulama ya da hücrelerin mikro çevrelerinde herhangi bir değişim ya antioksidan cevabı düşürerek neden olarak serbest radikaller ve bu radikallerin ürünü olan ROS miktarının 
artmasına ya da antioksidan cevabi arttırarak serbest radikaller ve ROS seviyesinde azalmaya neden olabilmektedir. Çalışmamızda MCF-7 hücrelerinde $\mathrm{Kv} 1.3$ ve $\mathrm{Kv} 10.1$; MDA-MB-231 hücrelerinde ise $\mathrm{Kv} 1.3$ kanallarının inhibisyonu sonucu oksidatif stres seviyesinde azalmasina belirlendi. Azalma görülen bu kanser hücrelerinin antioksidan savunmalarının, serbest radikaller tarafindan üretilen ROS'lara göre daha yüksek olduğunu gösterdi. Ancak, MDA-MB-231 hücrelerinde Kv 10.1 kanalı inhibe edildiğinde, antioksidan savunmanın, serbest radikaller tarafından üretilen ROS'lara göre yetersiz olması sonucunda oksidatif stres oluştuğu gözlendi.

Sağlıklı hücrelerde olmasını istemediğimiz oksidatif stresin kanser hücrelerinde gözlenmesi meme kanseri ve Kv 10.1 kanalı arasındaki etkileşime farklı bir bakış açısı oluşturmuştur. VGPC'lerin inhibisyonunun kanser hücrelerinde oksidatif stres oluşturabileceği belirlenmiştir. Ayrıca, kanser hücrelerinde oksidatif stres oluşumunun kanser hücrelerinin metastatik karakteri ve inhibe edilen iyon kanalının türüne bağlı olduğu gözlenmiştir. Bu çalışma bu alanda yapılacak çalışmalara bir ön veri sağlamaktadır. VGPC'lerin meme kanserinin önlenmesi, moleküler ve hedefe yönelik tedavisine katk1 sağlanacağı düşünülmektedir.

Çıkar Çatışması Beyanı: Yazarlar çıkar çatışması olmadığını bildirmişlerdir.

Finansal Destek: Bu çalışma her hangi bir fon tarafından desteklenmemiştir.

Declaration of Conflicting Interests: The authors declare that they have no conflict of interest.

Financial Disclosure: No financial support was received.

\section{KAYNAKLAR}

1. Lavanya G, Sivajyothi R, Manjunath M, Parthasarathy PR. Fate of biomolecules during carbon tetrachloride induced oxidative stress and protective nature of Ammoniac baccifera Linn.: A natural antioxidant. International Journal of Green Pharmacy. 2009; 3:3005.
2. Yoshihara D, Fujiwara N, Suzuki K. Antioxidants: Benefits and risks for long-term health. Maturitas. 2010; 67:103-7.

3. Cejas P, Casado E, Belda-Iniesta C, et al. Implications of oxidative stress and cell membrane lipid peroxidation in human cancer (Spain). Cancer Causes Control. 2004; 15:707-19.

4. Laurent A, Nicco C, Chereau C, et al. Controlling tumor growth by modulating endogenous production of reactive oxygen species. Cancer Res. 2005; 65:948-56.

5. Skrzydlewska E, Kozuszko B, Sulkowska M, et al. Antioxidant potential in esophageal, stomach and colorectal cancers. Hepatogastroenterology. 2003; 50:126-31.

6. Lehmann-Horn F, Jurkat-Rott K. Voltage-gated ion channels and hereditary disease. Physiol Rev. 1999; 79:1317-72.

7. Zhang L, Zou W, Zhou SS, Chen DD. Potassium channels and proliferation and migration of breast cancer cells. Sheng Li Xue Bao. 2009; 61:15-20.

8. Nerbonne JM, Kass RS. Molecular physiology of cardiac repolarization. Physiol Rev. 2005; 85:1205-53.

9. Cahalan MD, Chandy KG. The functional network of ion channels in $\mathrm{T}$ lymphocytes. Immunol Rev. 2009; 231:59-87.

10. Pardo LA, Stuhmer W. The roles of $\mathrm{K}(+)$ channels in cancer. Nat Rev Cancer. 2014;14:39-48.

11. Brevet M, Fucks D, Chatelain D, et al. Deregulation of 2 potassium channels in pancreas adenocarcinomas: implication of KV1.3 gene promoter methylation. Pancreas. 2009; 38:649-54.

12. Jang SH, Kang KS, Ryu PD, Lee SY. Kv1.3 voltage-gated $\mathrm{K}+$ channel subunit as a potantial diagnostic marker and therapeutic target for breast cancer. BMB Rep. 2009; 42:535-9.

13. Pardo LA, Contreras-Jurado C, Zientkowska M, et al. Role of voltage-gated potassium channels in cancer. J Membr Biol. 2005; 205:115-24.

14. Downie BR, Sanchez A, Knotgen H, et al. Eag1 expression interferes with hypoxia homeostasis and induces angiogenesis in tumors. The Journal of biological chemistry. 2008; 283:36234-40.

15. Yu SP. Regulation and critical role of potassium homeostasis in apoptosis. Prog Neurobiol. 2003; 70:363-86. 
16. Morton MJ, Chipperfield S, Abohamed A, et al. $\mathrm{Na(+)-}$ induced inward rectification in the two-pore domain $\mathrm{K}(+)$ channel, TASK-2. Am J Physiol Renal Physiol. 2005; 288:F162-9.

17. Jang SH, Choi SY, Ryu PD, Lee SY. Anti-proliferative effect of Kv1.3 blockers in A549 human lung adenocarcinoma in vitro and in vivo. Eur J Pharmacol 2011; 651:26-32.

18. Laniado ME, Fraser SP, Djamgoz MB. Voltage-gated $\mathrm{K}(+)$ channel activity in human prostate cancer cell lines of markedly different metastatic potential: distinguishing characteristics of PC-3 and LNCaP cells. The Prostate. 2001; 46:262-74.

19. Ahidouch HO, Ahidouch A. K+ Channel Expression in Human Breast Cancer Cells: Involvement in Cell Cycle Regulation and Carcinogenesis. J Membrane Biol. 2008; 221:1-6.

20. Feng JF, Lu L, Zeng $\mathrm{P}$, et al. Serum total oxidant/antioxidant status and trace element levels in breast cancer patients. International journal of clinical oncology. 2012; 17:575-83.

21. Pande D, Negi R, Khanna S, et al. Vascular endothelial growth factor levels in relation to oxidative damage and antioxidant status in patients with breast cancer. J Breast Cancer. 2011; 14:181-4.

22. Abdul M, Santo A, Hoosein N. Activity of potassium channel-blockers in breast cancer. Anticancer Res. 2003;23: 3347-51.

23. Leanza L, Venturini E, Kadow S, et al. Targeting a mitochondrial potassium channel to fight cancer. Cell Calcium. 2015; 58:131-8.

24. Szabò I, Soddemann M, Leanza L, et al. Single-point muta-tions of a lysine residue change function of Bax and Bcl-xL expressed in Bax-and Bak-less mouse embryonic fibroblasts: novel insights into the molecular mechanisms of Bax-induced apoptosis. Cell Death Differ. 2011; 18:427-38.

25. Leanza L, Henry B, Sassi N, et al. Inhibitors of mitochondrial Kv1.3 channels induce Bax/Bakindependent death of cancer cells. EMBO molecular medicine. 2012; 4:577-93.

26. Leanza L, Trentin L, Becker KA, et al. Clofazimine, Psora-4 and PAP-1, inhibitors of the potassium channel Kv1.3, as a new and selective therapeutic strategy in chronic lymphocytic leukemia. Leukemia. 2013; 27:1782-5.
27. Malinska D, Mirandola SR, Kunz WS. Mitochondrial potassium channels and reactive oxygen species. FEBS letters. 2010; 584:2043-8.

28. Leanza L, Zoratti M, Gulbins E, Szabo I. Induction of Apoptosis in Macrophages via Kv1.3 and Kv1.5 Potassium Channels. Current Medicinal Chemistry. 2012; 19:5394-404.

29. Dooley KE, Obuku EA, Durakovic N, et al. World Health Organization group 5 drugs for the treatment of drug-resistant tuberculosis: unclear efficacy or untapped potential? The Journal of infectious diseases. 2013; 207:1352-8.

30. Wang $\mathrm{Q}, \mathrm{Hu} \mathrm{W}$, Lei $\mathrm{M}$, et al. MiR-17-5p impairs trafficking of H-ERG $\mathrm{K}+$ channel protein by targeting multiple er stress-related chaperones during chronic oxidative stress. PLoS One 2013; 8.

31. Spitzner M, Martins JR, Soria RB, et al. Eag1 and Bestrophin 1 are up-regulated in fast-growing colonic cancer cells. The Journal of biological chemistry. 2008; 283:7421-8.

32. Agarwal JR, Griesinger F, Stuhmer W, Pardo LA. The potassium channel Ether a go-go is a novel prognostic factor with functional relevance in acute myeloid leukemia. Molecular cancer. 2010; 9:18.

33. Ouadid-Ahidouch $\mathrm{H}$, Le Bourhis $\mathrm{X}$, Roudbaraki M, et al. Changes in the K+ current-density of MCF-7 cells during progression through the cell cycle: possible involvement of a h-ether.a-gogo $\mathrm{K}+$ channel. Receptors Channels. 2001; 7:345-56.

34. Hammadi M, Chopin V, Matifat F, et al. Human ether a-gogo $\mathrm{K}(+)$ channel 1 (hEag1) regulates MDA-MB-231 breast cancer cell migration through Orai1-dependent calcium entry. Journal of cellular physiology. 2012; 227:3837-46.

35. Garcia-Becerra R, Diaz L, Camacho J, et al. Calcitriol inhibits Ether-a go-go potassium channel expression and cell proliferation in human breast cancer cells. Experimental cell research. 2010; 316:433-42. 